\title{
Performance Analysis of Wind Power Generation Models Using Oscillating Water Column
}

\author{
Susastro $^{1}{ }^{*}$, Ardi Noerpamoengkas ${ }^{2}$, Miftahul Ulum ${ }^{3}$, Gatot Setyono ${ }^{4}$ \\ 1)Vocational School, Diponegoro University \\ Hayamwuruk Street, Peleburan, Semarang, 50241,Indonesia \\ 2,3,4)Mechanical Engineering Dept. Adhi Tama Surabaya Institut of Technology \\ Arif Rahman Hakim Street, 60111, Surabaya \\ *email:sastrom51@gmail.com
}

\begin{abstract}
DOI;
10.30595/jrst.v4i2.6020

In this global era there are many resources that can be used one of them is, renewable resources such as sea waves. waves can be used as a generated of electrical energy. electrical energy that utilizes the occurrence of sea waves now can be applied in developed and developing countries. One method of conversion that can be done to convert wave energy into

Received:

$2019 / 11 / 29$ electrical energy is by using an oscillating water column. In this research, the turbine of oscillating water column was made using turbine wells with variations in rotation at 40,50 and $58.3 \mathrm{rpm}$. the results it's power of

Revised: $2020 / 05 / 27$ turbine, power of generator and efficiency system. The method used is the experimental method by testing the prototype using a low water wave on a laboratory scale. The results obtained from the experiment are that the

Accepted: $2020 / 07 / 25$ electric power at the maximum load generated by the generator is 0.002875 Watt at a rotation of $50 \mathrm{rpm}$. While the lowest electric power at maximum load is $0.0004 \mathrm{~W}$ with a rotation of $40 \mathrm{rpm}$. The maximum efficiency of the system at load is $4.691 \%$ which occurs at a rotation of 50 rpm.
\end{abstract}

Key Words: Wave, turbine wells, oscillating water column.

\section{INTRODUCTION}

Indonesia is an archipelago that has many islands and vast oceans. Where the area of Indonesia includes waters and coastlines. Therefore Indonesia has many opportunities in developing renewable energy, one of which is energy related to ocean waves (Lejerskog, Boström, Hai, Waters, \& Leijon, 2015; O’Sullivan \& Lewis, 2008). There are many ways in utilizing sea wave energy into electrical energy, among others, by using a translational transformer into a rotational motion and finally making a rotational motion on the generator as practiced by (Miftahul Ulum, 2018). From the research results obtained that the wave energy generated from the laboratory scale testing pool the energy produced is 0.9018 watts. While the electrical energy produced at the actual ocean scale by the mechanism is 95.97 watts at a sea wave height of 2.9 meters.
Indonesian seas, especially in Java sea waters, have an average wave height of 2,986 meters with wavelengths between 559,017 and 883,883 meters and periods of 56,579 and 89,360 seconds (Nadzir, Jaelani, \& Sulaiman, 2016; Tae, Jasron, \& Koehuan, 2015) conducted a study by planning turbine wells used in the mechanism of sea wave power generation (PLTGL) using oscillations of water columns with a capacity of $10 \mathrm{~kW}$. From the results of the study it can be concluded that the electric power generated by ocean waves using PLTGL-OWC can be produced with the smallest energy of 563.3089 Joules in March and April, while the largest energy produced is 3,762,948.04 Joules in March and April. For the use of the Wells turbine with a simulation that is used to produce turbine mechanical power of 15031, 13 Watt, with $24.544 \%$ water column oscillation efficiency. 
Conducted a study which also discussed the Oscilating Water Column (OWC) system in thirty Indonesian marine areas (Indonesia et al., 2010) . From the research obtained by coastal waters in Indonesia has the potential that can be used to implement the oscillating water column PLTGL system. Where the smallest power that can be produced is 246,0294 watts in the Malacca Strait waters. The biggest power that can be produced is $1,968,235$ watts in the southern waters of Banten to the West Java, southern waters of Central Java, the southern waters of East Java and the Arctic Sea Waters. (Wijaya, 2010) conducted the same research in the waters of Bali. From the results of his research it can be concluded using the ocean wave power plant oscilatting water column method in the Jimbaran sea region producing the largest energy is $16,478,982.17$ Joules and the lowest is $92,5897 \mathrm{~J}$. while for the electric power generated is $4,174,007$ watts and the lowest is 175.89 watts. . At the location of placement at a depth of $50 \mathrm{~m}$ above sea level and a distance of approximately $2.8 \mathrm{~km}$ from the Jimbaran coastline. Sea wave power plants using the oscilatting water column method can be seen in Figure 1.

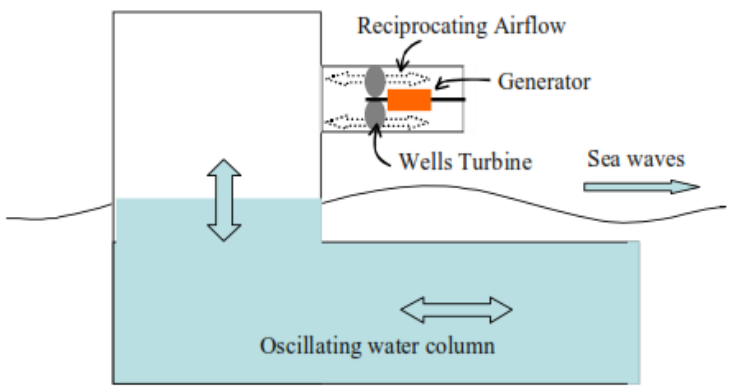

Figure 1. Schematic of ocean wave movement on oscillating water column (Kazmierkowski \& Jasiński, 2010)

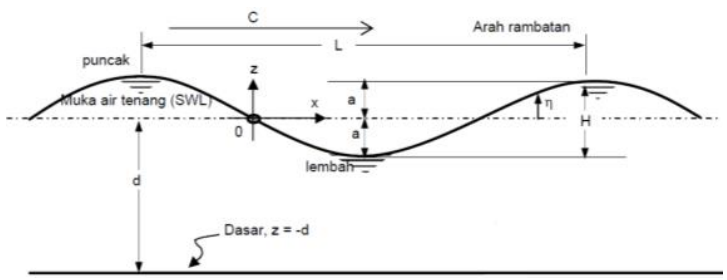

Figure 2. Sea wave in $\mathrm{x}-\mathrm{z}$ coordinate (Sebastian Brusca et al., 2017)
OWC is one of the systems and equipment that can convert ocean wave energy into electrical energy by using oscillation columns (Michael E Mc Cormick, 2010). This OWC tool will capture the wave energy that hits the OWC door opening, resulting in fluctuations or oscillations of water movement in the OWC space, then this air pressure will drive the turbine blades that are connected to an electric generator so as to produce electricity. In this OWC technology, air pressure from a waterproof room is used to drive the turbine whells which later on the movement of this turbine is used to produce electrical energy (S. Brusca, Lanzafame, \& Messina, 2014; Sebastian Brusca et al., 2015) The theory of ocean waves was first proposed by Airy in 1845 . The modeling of linear sea waves is shown in Figure 2 below.

Figure 2 shows a wave in the $x-z$ corninate system. Waves move on the $\mathrm{x}$-axis with wave heights $H(m)$, wavelength $L(m)$, and SWL or mean sea water level (calm water level). Wave potential energy can be written with the following equation.

$$
\mathrm{E}=1 / 2 \rho g \mathrm{~A}^{\wedge} 2 \ldots
$$

Where $\mathrm{E}$ is the wave potential energy (joules), $g$ the acceleration due to gravity, $\rho$ water density, and A amplitude (meters).

In previous research there was no discussion about testing ocean wave power generation systems using OWC. therefore in this research we will using OWC (oscilating water column) system with wells turbin in laboraturium scale. rotational speed is given a change between 40,50 , and $58.3 \mathrm{rpm}$.

\section{METHOD}

The experimental method is used, where the first step is done by designing the OWC prototype that will be used. the next step is to determine the materials and equipment that will be used in making OWC prototypes, then determine the speed of the motor that will be used in the experiment. In testing the OWC prototype variations of the parameters used are motor speed with rotation of $40 \mathrm{rpm}, 50 \mathrm{rpm}$, and $58.3 \mathrm{rpm}$. The prototype is shown in Figure 3. 


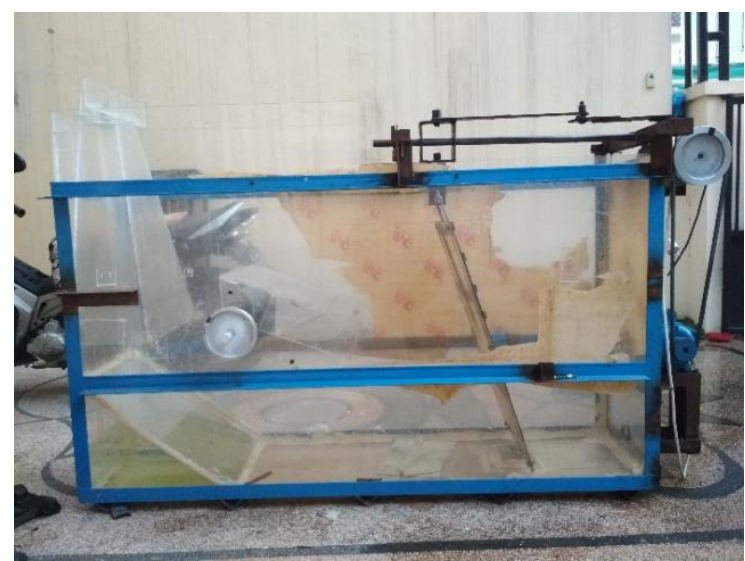

Figure 3. Prototype OWC

Figure 3 is a prototype of the $\mathrm{OWC}$ that is used as a experimental tools. The experiment is done by making an oscillation wave using a drive motor with power $1 / 4 \mathrm{Hp}$, rotational speed of $1400 \mathrm{rpm}$, then the motor rotation will be transmitted to the pulley and drive the gear ratio connected to the oscillation wave making mechanism. Furthermore, the wave will enter the OWC column in which there is space that will form an air movement which circulates in accordance with the waves that enter the OWC system. The air that is circulating will drive the turbine wells that are in the system. As for the image of the turbine wells shown in Figure 4.

Figure 4 is a turbine wells design made for the prototype of the OWC system. Turbine wells that are driven by air flow due to vacuum will rotate to move the generator. The specifications of the turbine wells used are shown in Table 1.

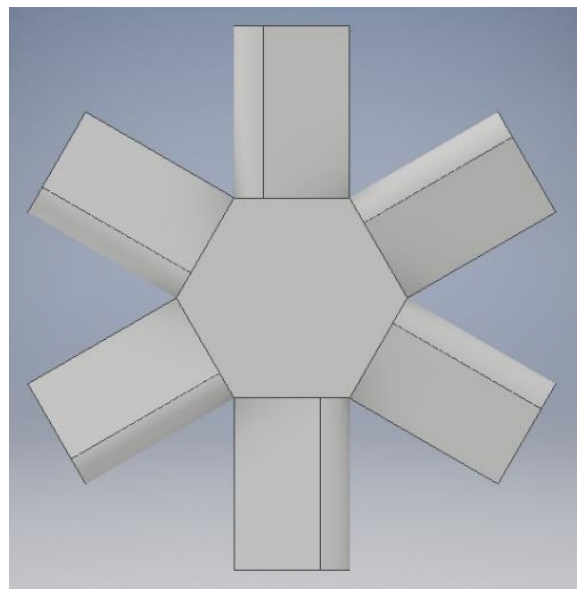

Figure 4. Tubin wells used in OWC systems
Table 1. Weels Turbine Specification

\begin{tabular}{lll}
\hline No. & Parameter & Dimension \\
\hline 1 & Diameter & $97 \mathrm{~mm}$ \\
2 & Thicknes & $10 \mathrm{~mm}$ \\
3 & Blade width & $20 \mathrm{~mm}$ \\
4 & Blade Angle & $18.26^{\circ}$ \\
5 & Blade width & $20 \mathrm{~mm}$ \\
6 & Blade Long & $30 \mathrm{~mm}$ \\
\hline
\end{tabular}

The DC generator used in the OWC system, while the 2 LED lamps in parallel arrangement as an electrical load. Electrical loading is done by varying one lamp and a maximum load of 2 lights. The measurement tools are multi tester, tachometer, amperage pliers, and anemometer. Experiments were conducted to determine the power generated by the OWC system with variations in rotational speed between 40, 50 and $58.3 \mathrm{rpm}$ and to determine the efficiency of the prototype OWC system.

\section{RESULT AND DISCUSION}

From the experimental results using the OWC system with well turbine, we generate the system performance as figure 5 . From Figure 5 it can be seen that variations in gear rotational speed can affect the wave height that occurs. the wave height reaches $0.19 \mathrm{~m}$ at a rotational speed of $40 \mathrm{rpm}$, the wave height reaches $0.25 \mathrm{~m}$ at a rotational speed of $50 \mathrm{rpm}$, and the wave height reaches $0.13 \mathrm{~m}$ at a rotational speed of $58.3 \mathrm{rpm}$. from this condition it can be concluded that the optimal rotation that can be given to the OWC system is $50 \mathrm{rpm}$. if the system is given a higher spin, then the oscillation of the resulting wave will not be stable and will damage the frequency of the waves caused.

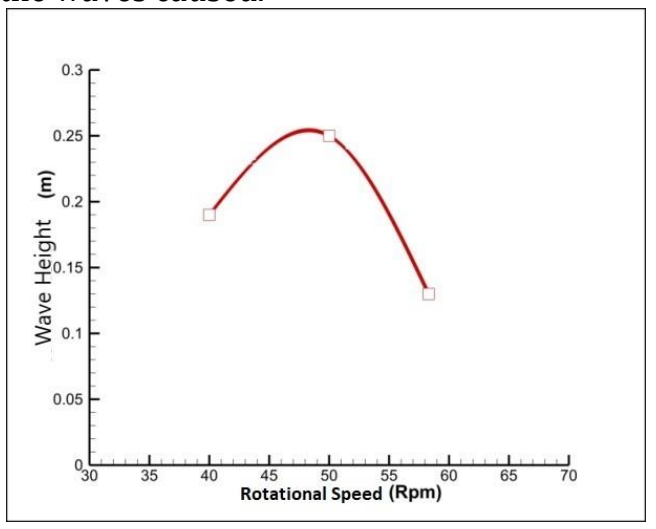

Figure 5. Wave height as a function of rotational speed 


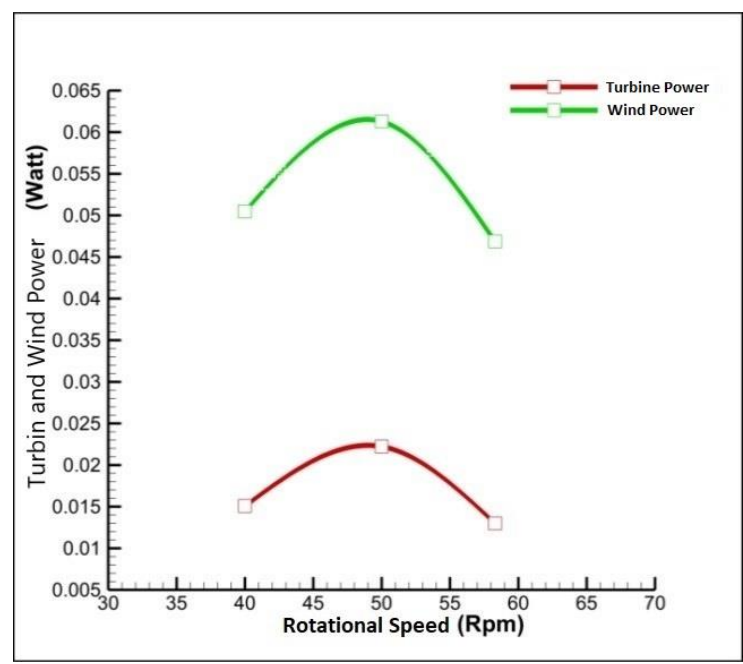

Figure 6. Comparison of turbin power and win power

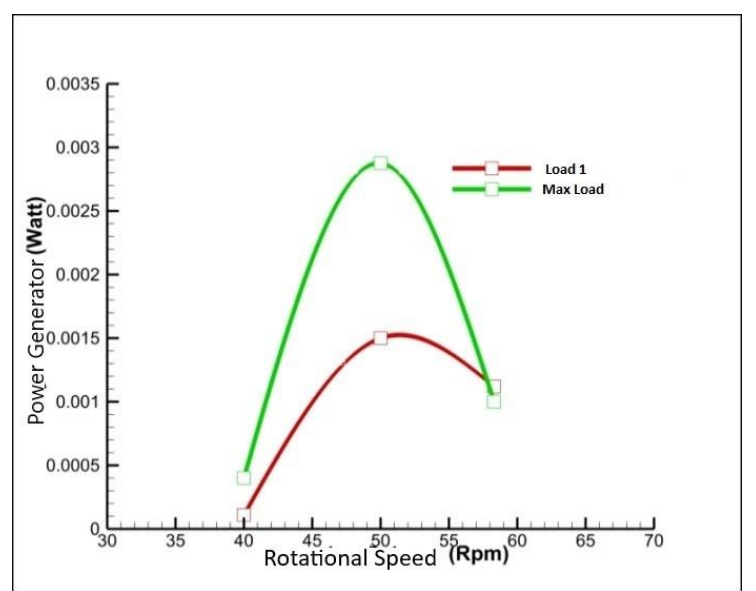

Figure 7. Comparison of power generator in $\max$ load and load 1

The results of rotational speed change on turbine and wind power obtained the highest value of power generation occurs at $50 \mathrm{rpm}$ rotation, with wind power 0.06128 watts and turbine power 0.022227 watts. While the lowest power at $58.3 \mathrm{rpm}$ rotation. From these results it can be said that in OWC systems wave height greatly influences system performance.

From Figure 7 it can be seen that the rotation speed affects the power produced by the generator. Where the highest power occurs at 50 rpm speed with a single lamp load of 0.001500 Watt power and a maximum load of 0.002875 Watt. The lowest power occurs at a rotational speed of $40 \mathrm{rpm}$ with a single lamp generator power load of 0,000110 Watt and a maximum load of 0,0004 Watt.

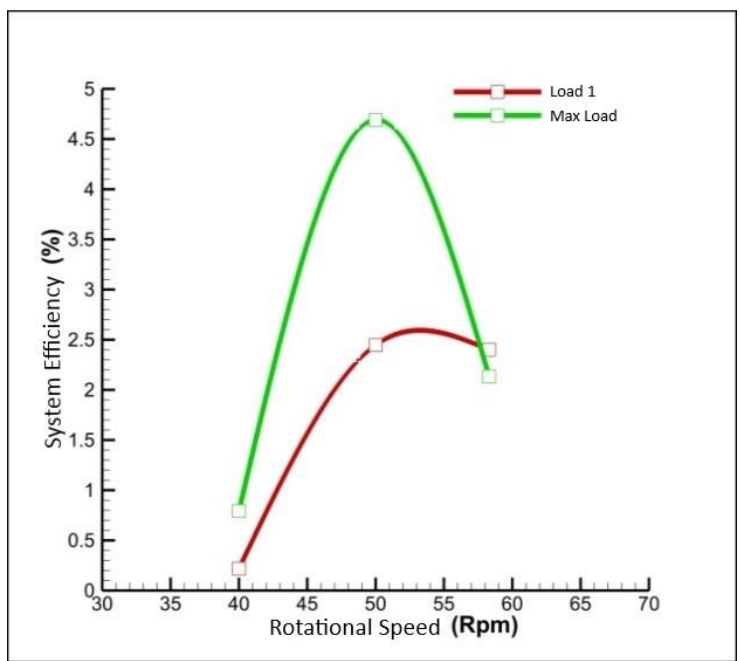

Figure 8. Comparison efficiency sistem in max load and load 1

The effect of speed variations on the efficiency of the system has the same trend line as Figure 8. the power produced will be even greater with greater efficiency. but the power produced will be smaller if the resulting efficiency is low. the highest efficiency curve occurs at a speed of $50 \mathrm{rpm}$ with an efficiency at a load of $2.447 \%$ and a maximum load efficiency of $4.691 \%$. while the lowest efficiency occurs at a rotational speed of $40 \mathrm{rpm}$ with a lamp load efficiency of $0.218 \%$ and a maximum load efficiency of $0.793 \%$.

\section{CONCLUSION}

The biggest power produced by the OWC system is 0.0222271 Watt and occurs at a rotating speed of $50 \mathrm{rpm}$. While the smallest power generated is 0.0129979 Watt at $58.3 \mathrm{rpm}$ rotational speed. The largest electric power generated by the generator at a lamp load of 0.0015 Watt and a maximum load of 0.002875 Watt that occurs at a gear rotation speed of 50 rpm. While the lowest power at the load of one lamp is $0,000110 \mathrm{Watt}$ and the maximum load is 0,000400 Watt which occurs at a rotational speed of $40 \mathrm{rpm}$. The greatest system efficiency produced in turbine wells at a single lamp load of $2.447 \%$ and a maximum load of $4.691 \%$ which occurs at a rotational speed of $50 \mathrm{rpm}$. In the OWC system the wave height influences the rotation produced by the turbine wells, which of course will affect the power and rotation generated by the generator. 


\section{BIBLIOGRAPHY}

Brusca, S., Lanzafame, R., \& Messina, M. (2014). Design of a vertical-axis wind turbine: how the aspect ratio affects the turbine's performance. International Journal of Energy and Environmental Engineering, 5(4), 333-340. https://doi.org/10.1007/s40095-0140129-x

Brusca, Sebastian, Cucinotta, F., Galvagno, A., Lanzafame, R., Mauro, S., \& Messina, M. (2015). Oscillating Water Column Wave Energy Converter by means of straightbladed Darrieus turbine. Energy Procedia, 82, $\quad$ 766-773. https://doi.org/10.1016/j.egypro.2015.11. 809

Brusca, Sebastian, Galvagno, A., Lanzafame, R., Cugno Garrano, A. M., Mauro, S., \& Messina, M. (2017). On the turbine-induced damping in Oscillating Water Column wave energy converter. Energy Procedia, 126, 581-588. https://doi.org/10.1016/j.egypro.2017.08. 215

Indonesia, U., Utami, S. R., Teknik, F., Studi, P., Elektro, T., \& Listrik, K. T. (2010). Gelombang Laut Dengan Menggunakan Sistem Oscilating Water Column (Owc) Di Tiga Puluh Wilayah Kelautan Indonesia Gelombang Laut Dengan Menggunakan Sistem Oscilating Water Column ( Owc) Di Tiga Puluh Wilayah Kelautan Indonesia.

Kazmierkowski, M. P., \& Jasiński, M. (2010). Power electronics for renewable sea wave energy. Proceedings of the International Conference on Optimisation of Electrical and Electronic Equipment, OPTIM, 4-9. https://doi.org/10.1109/OPTIM.2010.551 0476

Lejerskog, E., Boström, C., Hai, L., Waters, R., \&
Leijon, M. (2015). Experimental results on power absorption from a wave energy converter at the Lysekil wave energy research site. Renewable Energy, 77, 9-14. https://doi.org/10.1016/j.renene.2014.11. 050

Michael E Mc Cormick. (2010). Ocean Engineering Mechanics. In Cambridge (Vol. 1).

Miftahul Ulum. (2018). Jurnal iptek. Jurnal IPTEK, 11(1), 29-36. https://doi.org/10.31284/j.iptek.2018.v22 i2

Nadzir, Z. A., Jaelani, L. M., \& Sulaiman, A. (2016). Estimasi tinggi gelombang laut menggunakan citra satelit alos-palsar. Jurnal Geosaintek, 02(03), 173-184. https://doi.org/10.12962/j25023659.v2i3. 2102

O'Sullivan, D. L., \& Lewis, A. W. (2008). Generator selection for offshore oscillating water column wave energy converters. 2008 13th International Power Electronics and Motion Control Conference, EPE-PEMC 2008, 17901797.

https://doi.org/10.1109/EPEPEMC.2008.4 635525

Tae, V., Jasron, J. U., \& Koehuan, V. A. (2015). Perencanaan Turbin Wells Sistem Osilasi Kolom Air pada Pembangkit Listrik Tenaga Gelombang Laut dengan Kapasitas $10 \mathrm{~kW}$. LONTAR Jurnal Teknik Mesin Undana (LJTMU), 02(02).

Wijaya, I. W. A. (2010). Pembangkit Listrik Tenaga Gelombang Laut Menggunakan Teknologi Oscilating Water Column Di Perairan Bali. Majalah Ilmiah Teknik Elektro, 9(2), 165-174. https://doi.org/10.24843/10.24843/MITE 